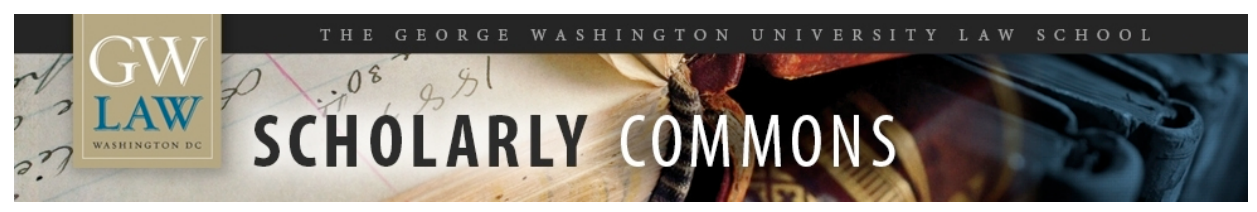

\title{
Class, politics, gender and the marriage divide in the United States
}

Naomi R. Cahn

George Washington University Law School, ncahn@law.gwu.edu

June Carbone

Follow this and additional works at: https://scholarship.law.gwu.edu/faculty_publications

Part of the Law Commons

\section{Recommended Citation}

Cahn, Naomi and Carbone, June, Class, Politics, Gender and the Marriage Divide in the United States (2015). Families, Relationships and Societies, vol. 4, issue 1, p. 163-9 (2015).

This Article is brought to you for free and open access by the Faculty Scholarship at Scholarly Commons. It has been accepted for inclusion in GW Law Faculty Publications \& Other Works by an authorized administrator of Scholarly Commons. For more information, please contact spagel@law.gwu.edu. 
Class, Politics, Gender, and the Marriage Divide in the United Sates

June Carbone and Naomi Cahn

\begin{abstract}
We use the idea of the "marriage divide" to describe the transformation of the family to meet the needs of the information economy and the divisions that the transformation has created. In doing so, we emphasize three types of "marriage divides" in the United States: class and racial ideological and political, and family law/gender ideology.
\end{abstract}

\title{
Introduction
}

In the United States, the drumbeat from social conservatives has been incessant. For well over a generation, political and religious conservatives, with the support of many in the center, have claimed that the changing family is a societal disaster, gay marriage a threat to morality, and single parent families a major cause of poverty and inequality. Coupled with the cries of alarm has been what we have called a "red", typically Republican, agenda that insists on reaffirming the traditional celebration of the identity of sex, marriage and procreation as the natural (and divinely ordained) order for insuring children's well-being (Douthat, 2014). Roll back the clock and presumably all will be well.

The left, and many in the center, predictably recoil from these claims. As a cultural matter, modernists and those we have termed politically "blue" oppose any appeal to tradition, much less the "divinely ordered" family of breadwinning heterosexual men and stay-at-home wives that they accurately see as a relic of the industrial era. They are more inclined to celebrate individual choice and to encourage material well-being, whether this produces single-parent families, same-sex partnerships, Islamic marriage contracts, or old-fashioned church wedding with brides veiled in white. At least as fundamentally, they see the calls to restrict abortion (along with contraception and sex education) and to promote marriage (particularly by restricting divorce) as part of a wholesale attack on women's autonomy.

This cultural debate, as modernists and traditionalists shout past each other in the political sphere, obscures the question of marriage in securing children's well-being. All other things being equal, after all, two parents are better than one and stability is better than chaos, especially in the lives of young children. Indeed, the argument for the superiority of two parents is tautological. (Amato, 2002: 71-94). Two parents, by definition, have more time than one parent (at least if they are not spending all their additional time fighting with each other). Two parents struggling to balance work and family obligations still typically end up with higher incomes than a single parent. Yet marriage has emerged as a marker of class, effectively beyond the reach of large parts of the population.

This paper discusses how marriage has emerged as a "divide" that exacerbates class and race-based inequalities in the United States and triggers deep ideological divisions in crafting the appropriate legal and policy responses. We emphasize three types of "marriage divides": first, class and racial disparities, second, the ideological clash between red and blue that frames the proposed responses, and third, legal differences that affect the relative balance of power between men and women.. The paper concludes that these divides can be bridged only with recognition that greater equality is a necessary precondition to more stable unions, children's well-being 
requires something more than exclusive reliance on two-parent heterosexual unions, and ideological conflicts are blocking forward movement.

\section{The marriage divide: class and race}

Increasing income inequality has remade American society, and the biggest winners and losers in the new economy are men, particularly white men. The result changes the way that men and women match up: there are more men at the top of the economy eager to pair with a smaller group of successful women. Marriage is thriving for this group. (Carbone \& Cahn, 2014). At the bottom, a large percentage of men have become effectively unmarriageable due to high rates of chronic unemployment, mass incarceration and substance abuse; marriage is rapidly disappearing in these communities. (McLanahan, 2004; Wilcox \& Marquardt, 2010). In the middle, both employment and family life have become less stable. The white women who graduate from high school, but not college, have a higher number of cohabitations, married or unmarried, than any other group in American society (Cherlin, 2011). These developments make family a marker of more deeply etched class boundaries.

These results do not reflect differences in the nature or desirability of marriage. Indeed, sociologists find that all communities value marriage similarly: as an unconditional commitment to create an interdependent union with a partner who will share in the joys and obligations of creating a family (Carbone \& Cahn, 2014) However, as greater inequality has changed the way men and women relate to each other, it has changed their expectations about whether they will ever find a partner worthy of such commitment.

These changes reflect "marriage markets," that is, the definitions of who is likely to marry whom. When men outnumber women in any given marriage pool, the men must compete for access to desirable women and they invest more in their own income, status and acceptable behavior. (Guttentag \& Secord, 1983). When, instead, women outnumber the men, the men tend to play the field. Women, jaded after a few bad experiences with men, become pickier and invest more in themselves and their children, relying less on intimate partners. In a more unequal society, marriage markets become more segmented as elites become more likely to marry later and to marry each other. The more segmented the markets, the more they can develop in different directions.

Studies of marriage find that income and education matter in the choice of a mate: people are more likely to marry partners like themselves, and warier about partners who cannot pull their own weight (Greenwood, et al., 2014; Schwartz \& Mare, 2011). When they do marry, the successful men see themselves as competing for the top women (Schwartz, 2010:1524). At a time of declining marriage rates, the only group in society whose marriage rates have increased is the top 5 percent of women defined by income. These women, taken together with the comparable group of men, constitute the societal sector where gender-based income differences have grown most markedly and where highly paid men are most likely to outnumber and outearn highly paid women (Greenstone \& Looney, 2012). While the effects are not as dramatic, the emphasis on marriage has increased for the larger group of college graduates as a whole. Among this group, the divorce rate has fallen substantially since 1990 even as it has increased for the rest of society, the non-marital birth rate, as least among whites, has remained low, and the likelihood that the children of college graduate parents are in two-parent homes increased between 1982 and 2006 for both whites and African-Americans (McLanahan, 2004; Wilcox \& Marquardt, 2010). 
The result is the emergence of marriage as a marker of class. College graduates invest in their education and careers. They postpone family formation until they have the financial security and emotional stability to devote themselves to children. In the rest of society, stable women find reliable men increasingly hard to find. They see little point in postponing childbearing for an event they do not expect to happen. Instead, they invest in themselves and rely on relatives to help care for their children. Both groups see marriage as a partnership premised on commitment and trust, but they do not share similar levels of confidence in the ability to realize that ideal.

\section{The Marriage Divide: Ideology and Public Policy}

Scholars agree that changing marriage rates reflect a combination of women's greater independence and the declining fortunes of blue collar men. (Carbone \& Cahn, 2014) They disagree profoundly, however, about appropriate responses. A major reason is that the debate over marriage maps onto an increasing ideological divide that frames political choices.

Over the last thirty years, American politics have become increasingly polarized, particularly among partisan activists: political polarization maps onto basic underlying values orientations. In a metastudy of political attitudes, for example, Jost (2006) argues that the prevalence of "liberal" traits, such as openness to change, versus "conservative" ones, such as the veneration of tradition, is a major factor in political loyalties and the party realignment that has occurred over the last twenty-five years (Jost, 2006: 654). These basic orientations frame attitudes toward the family. People with conservative approaches distrust change and tend to respond to greater insecurity with calls to renew the commitment to tradition. They therefore support calls for greater emphasis on marriage. Conservatives, who also tend to be more individualistic, blame the decline of marriage on deteriorating moral values. They respond to appeals framed in terms of absolutes, and oppose measures, such as sex education, that depend on nuanced messages. Liberals tend to be more egalitarian and pragmatic and often recoil from traditionalist emphasis on marriage. They support greater access to contraception and abortion, greater support for all children irrespective of family form, and greater efforts to remake the infrastructure that supports childrearing so that it is less dependent on marriage or on women's unpaid caretaking (Cahn \& Carbone, 2010).

This combination of more ideological politics, the family as a site of profound societal change, and the framing of the marriage debate in terms that overlap with underlying values orientations makes marriage the source of a fundamental political and policy divide. That divide produces different family law in different states on issues as basic as the recognition of legal parenthood and awarding custody.

\section{The Marriage Divide: Law and Gender}

The marriage debate collides with the reality that has produced different family systems at the top and the bottom of the new economic order. Within this, the family also stands on a new gender bargain. The renewed commitment to marriage at the top comes within a neo-patriarchal family law system. At the bottom, women enjoy more control of relationships outside of marriage than within it.

Elite women are willing to commit because of their ability to find men who offer the right combination of societal advantages (income, status or prestige) and acceptable behavior (fidelity, 
respect, companionship). Men in turn also commit when they find a true partner, one who helps them feel good about themselves and who enhances their ability to realize their ambitions and dreams. For the couples who make that commitment, family law serves traditional ends. It recognizes an interdependent economic union and splits the parties' assets if they divorce. It also recognizes a new norm of joint parenting, and accords equal custodial rights to men. This system makes it easier for elite spouses to enforce premarital agreements that insulate the assets of a wealthier spouse. It also allows the men with the assets to pursue custodial rights to secure continued involvement with their children. Married men are more likely than unmarried men to obtain shared custody orders after a split, and within each group, the more money a man has the more likely he is to enjoy shared custody (Brown \& Cook, 2012).

Failing committed partnerships, men get sex on their terms, and women manage the child on their terms (Edin \& Nelson, 2013: 214). They take responsibility for the child's financial and caretaking needs. To the extent a man helps out, he has continued access. To the extent he is jealous, abusive or an unreliable additional burden who demands too much of the mother's energies, his relationship with the child will be at risk. The women, as a general rule, support the child, though some certainly conflate their own interests with the child's needs. This model is essentially a single parent model, reflecting the "authentic" emerging bargain of the non-elite. It neither receives official support in the law nor can it. It is at odds with the new elite model and largely remains invisible. Women, who are not on welfare but who are not wealthy enough to make into the elite marriage markets, simply stay out of court - and out of marriage. The burden is on the man to establish paternity, and if he does, to get a custodial order, and then to enforce it.

As this system becomes more visible, however, it contradicts both traditionalist insistence on marriage and male authority and modernist notions of gender equality and equal rights for mothers and fathers. The result is a new effort to reimpose men on women and to insist on involving two parents in the child's life. This move, which is consistent with both conservative and liberal expectations about appropriate family behavior, does violence, however, to the reality of non-elite women's lives. They do not have the option of mating with reliable men, and they do not have the wherewithal to sever the father's parental rights as a matter of law. Legal reforms, which simplified paternity establishment in the Clinton era, now seek to help unmarried men to assert custodial rights and gain greater access to the courts (See generally Huntington, 2015) These efforts impose the elite gender bargain on the non-elite.

\section{Where next?}

While the existence of class-based differences is now well-documented, there is no agreement on solutions. Yet, there are two obvious ones, rarely discussed in explicit terms. The first recreates the links between stable jobs and stable families, and attempts to make the elite family model accessible to a larger percentage of the population. This approach accepts the importance of marriage, and advocates strategies that make it more likely that two partners will find advantages in parenting together. Such strategies require greater economic equality, more opportunities for blue-collar men, greater support for higher education and job training, and better access to contraception and other supports for delaying family formation. While this model includes economic policies associated with blue values, it overlaps with red ideology on the importance of marriage. 
What is the red alternative? Bring back patriarchy. Conservatives like Charles Murray blame changing values, charging that the men have become lazy because women no longer depend on them or fail to sleep with them until they shape up (Murray, 2012). What is the secret to bringing back female dependence and male virtue? Make the women desperate. Conservatives see single mothers as the problem. The "war on women” restricts access to contraception, abortion and divorce, limits public support for childrearing, and seeks to restore female dependence that makes marriage indispensable to childrearing.

Is there a third option? We believe there is. Whether or not it is possible to recreate a system of stable two parent families (the first alternative), the subordination of women is unacceptable (the second alternative). The alternative to greater coercion is recognition that family variety is likely to be a permanent feature of the new era, and that all parents, married or single, male or female, are likely to spend most of their adulthoods in the labor market. We have not yet remade the workplace to accommodate childrearing, nor have we marshaled the resources necessary to insure the minimum level of investment in children necessary to promote full citizenship in a new, more demanding era. Rebuilding the infrastructure for childrearing thus requires: 1) recognition that maturity is a plus for parenting and workforce participation and universal access to contraception and, if necessary, abortion, is an essential aspect of responsible parenting; 2) that just as free compulsory primary and secondary education became hallmarks of the industrial era, universal access to high quality early childhood education should define the information age; 3) creation of family-friendly workplaces for mothers and fathers to advance both gender equality and adequate support for childrearing; and 4) a well-constructed safety net that provides universal access to health care and assists parents' ability to move in and out of the workforce in accordance with children's needs. This system will provide greater support for parents who wish to trade-off childrearing responsibilities, but it will also make single parenting less perilous. To make such a system work, family law should recognize those who contribute to children rather than assume equality on the basis of biology alone. Ironically, the marriage divide as a marker of politics and privilege will end only when children's well-being no longer depends so exclusively on the strained resources parents can bring to the endeavor.

\section{References}

Amato, P, 2002, Good enough marriages: Parental discord, divorce, and children's wellbeing, Virginia Journal of Social Policy and the Law, 9, 71-94.

Brown, P \& Cook, S, 2012, Children's placement arrangements in divorce and paternity cases in Wisconsin, Institute for Research on Poverty University of Wisconsin-Madison, Cahn, N \& Carbone, J, 2010, Red families v. blue families: Legal polarization and the creation of culture, Oxford University Press.

Carbone, J. \& Cahn, N, (2014) Marriage markets: How inequality is remaking the American family, Oxford University Press.

Cherlin, A. (2011) Between poor and prosperous: Do the family patterns of moderately-educated Americans deserve a closer look?, in M. Carson and P. England (eds) Changing families in an unequal society, Stanford University Press, 68-84.

Douthat, R, (2014) More imperfect unions, The New York Times, January, 26, http://www.nytimes.com/2014/01/26/opinion/sunday/douthat-more-imperfect-unions.html. Edin, K \& Nelson, T, (2013), Doing the best I can: Fatherhood in the inner city, University of California Press. 
Greenstone, M \& Looney, A, (2012), The marriage gap: The impact of economic and technological change on marriage rates, Brookings, http://www.brookings.edu/upfront/posts/2012/02/03-jobs-greenstone-looney.

Greenwood, J, et al., 2014, Marry your like: Assortative mating and income inequality, National Bureau of Economic Research (NBER), January, Paper No. 19829, http://www.nber.org/papers/w19829).

Guttentag, M and Secord, P, (1983) Too many women? The sex ratio question, SAGE Publication Inc.

Huntington, C, (forthcoming 2015) Post-marital family law, Stanford Law Review. Jost, J. (2006) The end of the end of ideology, American Psychologist, 61, 7, 651-670. McLanahan, S. (2004) Diverging destinies: How children are faring under the second demographic transition, Demography, 41(4), 607-27.

Murray, C, (2012) Why Economics Cannot Explain Our Cultural Divide, Wall Street Journal, http://online.wsj.com/news/articles/SB10001424052702304692804577281582403394206.

Schwartz, C, \& Mare, R, (2011) Trends in Educational Assortative Marriage from 1940 to 2003, Demography, 43, 621-46.

Schwartz, R, (2010), Earnings inequality and the changing association between spouses' earnings, American Journal of Sociology, 115, 7, 1524-1557.

Wilcox, W \& Marquardt, E, (2010) When marriage disappears: the new Middle America, 23, National Marriage Project and Institute for American Values, December. 